\title{
HUBUNGAN ANTARA KANDUNGAN KLOROFIL-a DENGAN HASIL TANGKAPAN TONGKOL DI DAERAH PENANGKAPAN IKAN PERAIRAN PELABUHANRATU
}

\author{
Domu Simbolon dan Harry Satriyanson Girsang \\ Staf Pengajar pada Fakultas Perikanan dan Ilmu Kelautan, Institut Pertanian Bogor, Bogor \\ Teregistrasi I tanggal: 28 Mei 2009; Diterima setelah perbaikan tanggal: 24 Agustus 2009: \\ Disetujui terbit tanggal: 28 Oktober 2009
}

\begin{abstract}
ABSTRAK
Perairan Pelabuhanratu merupakan pusat penangkapan ikan yang potensial di Jawa Barat. Salah satu produk perikanan yang memiliki nilai ekonomis penting yang terdapat di perairan tersebut adalah ikan tongkol (Euthynnus affinis). Kandungan klorofil-a memegang peranan penting sebagai produser primer dalam ekosistem laut dan menjadi suatu indikator dalam pendugaan daerah penangkapan ikan. Tujuan penelitian ini adalah untuk menentukan hubungan antara kandungan klorofil-a dengan hasil tangkapan ikan tongkol, dan mengevaluasi daerah penangkapan tongkol di perairan Pelabuhanratu dalam periode bulan Maret-Mei 2007. Metode yang digunakan dalam penelitian ini adalah metode survei. Kandungan klorofil-a bulan Maret-Mei 2007 berkisar antara 0,240-0,600 mg $\mathrm{m}^{-3}$, dengan rata-rata $0,375 \mathrm{mg} \mathrm{m}^{-3}$. Jumlah tangkapan ikan tongkol bulan Maret 2007 mencapai $15.345 \mathrm{~kg}$ dengan produktivitas $272,27 \mathrm{~kg} / \mathrm{setting}$, bulan April 2007 meningkat sampai mencapai $62.638 \mathrm{~kg}$ dengan produktivitas $701,04 \mathrm{~kg} / \mathrm{setting}$. Selanjutnya pada bulan Mei 2007, jumlah ikan tongkol yang tertangkap hanya $8.258 \mathrm{~kg}$, tetapi produktivitasnya lebih tinggi dibandingkan bulan Maret, yaitu $401,55 \mathrm{~kg} / \mathrm{setting}$. Komposisi tangkapan ikan tongkol ukuran kecil pada bulan Maret-Mei 2007 mencapai $73 \%$ dari total tangkapan payang $82.641 \mathrm{~kg}$. Klorofil-a berpengaruh terhadap tangkapan ikan tongkol setelah 30 hari di perairan Pelabuhanratu. Dalam periode bulan Maret-April 2007, daerah penangkapan ikan tongkol paling potensial di perairan Pelabuhanraiu terdapat pada bulan April dibandingkan dengan buian Maret dan Mei 2007.
\end{abstract}

KATAKUNCl: klorofil-a, hasil tangkapan, ikan tongkol, daerah penangkapan ikan, perairan Pelabuhanratu

ABSTRACT: Relationship between chlorophyl-a concentration and frigate mackerel catches in fishing ground of Pelabuhanratu waters. By: Domu Simbolon and Harry Satriyanson Girsang

Pelabuhanratu waters is the central of potential fishing activities in West Java. One of its fisheries products which has an important economical value is frigate mackerel (Euthynnus affinis). Chlorophylla hold an important role as the primary producer in sea ecosystem and become one of indicator in fishing ground forecasting. The purposes of this study are to determine the correlation between chlorophyll-a concentration and frigate mackerel catches, and to evaluate fishing ground of frigate mackerel in Pelabuhanratu waters on March-May 2007. The method used in this research was survey method.Chlorophyll-a profile in March-May 2007 ranged from 0,240-0,600 mg m.3, with 0,375 mg $\mathrm{m}^{-3}$ in average. The amount of frigate mackerel catches in March reached $15.345 \mathrm{~kg}$ with $272,27 \mathrm{~kg} /$ setting in productivity value, in April, the catches increased to $62.638 \mathrm{~kg}$ with productivity about 701,04 $\mathrm{kg} / \mathrm{setting}$. In May 2007, the amount of frigate mackerel catches was remained $8.258 \mathrm{~kg}$, but the productivity was higher compared to productivity in March $(401,55 \mathrm{~kg} / \mathrm{setting}$ in CPUE's value). The composition of small frigate mackerel caught by boat seine net (payang) on March-May 2007 reached about $73 \%$ from $82.641 \mathrm{~kg}$ in totals. Chlorophyll-a concentration influenced significantly on frigate mackerel catches after 30 days in Pelabuhanratu waters. On the period of March-May 2007, the most potential fishing ground in Pelabuhanratu waters was found in April 2007 compared to March and May 2007.

KEYWORDS: chlorophyll-a, catch, frigate mackerel, fishing ground, Pelabuhan Ratu waters

\section{PENDAHULUAN}

Dalam penentuan daerah penangkapan ikan tongkol (Euthynnus affinis), nelayan payang Pelabuhanratu hanya menggunakan naluri alamiah yang didapat secara turun-temurun. Mereka belum mempertimbangkan perubahan parameter oseanografi yang mempengaruhi keberadaan ikan dalam perencanaan operasi penangkapan ikan. Waktu yang digunakan nelayan untuk mencari ikan relatif lama dan hasil tangkapan sedikit, bahkan pada periode waktu tertentu terkadang kosong yang berpengaruh terhadap rendahnya tingkat kesejahteraan nelayan. 
Keberadaan ikan di perairan bersifat dinamis, dan secara alamiah ikan akan bermigrasi untuk memilih habitat yang lebih sesuai akibat perubahan parameter oseonografi perairan, seperti suhu, arus, dan kesuburan perairan. Simbolon (2008) mengatakan bahwa sebaran temporal daerah penangkapan ikan tongkol di perairan Pelabuhanratu dipengaruhi oleh suhu permukaan laut. Namun demikian, keberadaan ikan tongkol di perairan tersebut tidak hanya dipengaruhi oleh sebaran suhu permukaan laut, tetapi juga diduga dipengaruhi oleh parameter-parameter lingkungan lain seperti penyebaran fitoplankton. $\mathrm{Hal}$ ini didasari oleh pemikiran bahwa fitoplankton sangat berperan sebagai primary producer dalam rantai makanan di perairan, yang selanjutnya dapat mempengaruhi kesuburan perairan dan keberadaan ikan, termasuk ikan tongkol. Menurut Nybakken (1992), indikator kesuburan perairan dapat diukur dari kandungan klorofil-a, karena klorofil-a merupakan pigmen yang paling umum terdapat pada fitoplankton dan berperan dalam proses fotosintesis.

Potensi sumber daya ikan tongkol di perairan Pelabuhanratu seyogyanya dapat lebih dioptimalkan pemanfaatannya melalui penyediaan informasi daerah penangkapan yang lebih akurat. Oleh karena itu, daerah penangkapan yang ada dewasa ini perlu dievaluasi untuk mengetahui apakah hasil tangkapan yang diperoleh nelayan selama ini masuk dalam kategori layak tangkap atau tidak. Di samping itu, pendugaan daerah penangkapan ikan tongkol yang potensial perlu dilakukan untuk lebih menghemat biaya dan waktu operasi penangkapan. Pendugaan daerah penangkapan ikan tongkol dalam penelitian ini dilakukan melalui analisis hubungan antara fitoplankton dengan hasil tangkapan. Informasi tentang sebaran fitoplankton dewasa ini relatif mudah diperoleh dengan menggunakan teknologi penginderaan jarak jauh (inderaja) melalui pendeteksian kandungan klorofil-a.

Dengan adanya informasi tentang sebaran daerah penangkapan ikan tongkol secara temporal, maka tingkat kepastian hasil tangkapan dapat ditingkatkan yang pada akhirnya dapat mengoptimalkan usaha penangkapan dan memperbaiki kesejahteraan nelayan payang melalui perencanaan waktu operasi penangkapan yang tepat. Luaran penelitian ini juga dapat sekaligus memperkaya pengetahuan, terkait dengan dinamika tingkah laku migrasi ikan tongkol akibat perubahan kandungan klorofil-a.

Tujuan penelitian ini adalah untuk menentukan hubungan antara kandungan klorofil-a dengan hasil tangkapan ikan tongkol dan mengevaluasi daerah penangkapan ikan tongkol di perairan Teluk Pelabuhanratu pada bulan Maret-Mei 2007

\section{BAHAN DAN METODE}

\section{Waktu dan Tempat Penelitian}

Penelitian dilaksanakan dalam dua tahap. Tahap pertama adalah pengumpulan data hasil tangkapan ikan tongkol di perairan Pelabuhanratu, Jawa Barat pada bulan Maret-Mei 2007. Tahap kedua dilaksanakan pada bulan Juli-Agustus 2007 dengan men-download citra klorofil-a dari internet (http:// oceancolor.gsfc.nasa.gov).

\section{Pengumpulan Data}

Metode yang digunakan dalam penelitian ini adalah metode survei, dengan mengikuti kegiatan penangkapan ikan tongkol menggunakan alat tangkap payang. Contoh kapal 10 unit, dilakukan secara sengaja atau purposive sampling terhadap alat tangkap payang yang menangkap ikan tongkol pada waktu penelitian. Dalam kegiatan operasi penangkapan yang dilakukan kapal contoh, dikumpulkan data tentang waktu operasi dan posisi penangkapan (setting). Pada setiap lokasi setting dicatat jumlah ikan tongkol yang tertangkap $(\mathrm{kg})$. Dari sejumlah hasil tangkapan tersebut selanjutnya diambil contoh ikan secara random untuk mengetahui ukuran panjang ( $\mathrm{cm} / \mathrm{ekor}$ ).

Data sebaran konsentrasi klorofil-a di lokasi penelitian diperoleh melalui cara mendownload hasil citra klorofil-a yang telah tersedia di internet. Data diperoleh melalui situs http:/l oceancolor.gsfc.nasa.gov. Data yang dipilih merupakan data harian sebaran klorofil-a Level 2 dengan batasan posisi $6,9^{\circ}-7,5^{\circ}$ LS dan $106,20^{\circ}$ $106,6^{\circ} \mathrm{BT}$.

\section{Analisis Data}

Untuk menentukan hubungan antara klorofil-a dan hasil tangkapan, maka dilakukan analisis korelasi dengan menggunakan software SPSS. Derajat hubungan dikatakan dengan koefisien korelasi ( $r$ ) yang merupakan akar dari koefisien determinasi $\left(R^{2}\right)$. Kisaran nilai koefisien korelasi adalah $-1 d \leq r d \leq+1$. Korelasi erat jika $r \geq 0,7$ dan $r \leq-0,6$, korelasi tidak erat jika $-0,6<r<0,7$.

Data sebaran klorofil-a diketahui dengan melakukan analisis visual terhadap citra MODIS yang telah terkoreksi dan ditampilkan dalam bentuk format 
gambar JPEG. Konsentrasi klorofil-a pada daerah penangkapan ikan pada saat trip operasi penangkapan dihitung dengan menggunakan software Seadas 4.7 dalam sistem operasi Linux. Citra klorofila kemudian diolah untuk mendapat konsentrasi berdasarkan pada posisi penangkapan yaitu Pelabuhanratu dan kemudian diproyeksikan dengan menggunakan proyeksi mercator. Perhitungan jumlah radiasi yang diterima oleh sensor satelit berdasarkan pada Rilley diacu dalam Surwagana et al. (2000) sebagai berikut:

$\log (C h l)=0,283-2,753+1,457 R^{2}+0,659 R^{3}-1,403 R^{4} \ldots \ldots \ldots . .(1$

$\mathrm{Chl}\left(\mathrm{mg} \mathrm{m}^{-3}\right)=10^{(0.283-2,753+1,457 \mathrm{R} 2+0,659 \mathrm{R} 3-1,403 \mathrm{R} 4)}$

di mana:

$\mathrm{Chl}=$ konsentrasi klorofil-a $\left(\mathrm{mg} \mathrm{m}^{3}\right)$

$\mathrm{R}=$ reflektansi (443)/reflektansi (551) atau rasio antara kanal 9 dan 12

Untuk memperbaiki tampilan citra, digunakan beberapa program yang terdapat dalam software Seadas 4.7, dengan tahapan sebagai berikut:

1. Coastline, merupakan program yang berfungsi untuk menampilkan garis pantai atau garis terluar dari pulau.

2. Color bar, untuk menampilkan skala warna konsentrasi citra yang telah dipilih.

3. Color lut, untuk memilih warna yang akan dipakai atau ditampilkan pada gambar citra.

4. Cursor position, untuk melihat nilai konsentrasi yang terdapat pada citra secara interaktif.

5. Grid line, untuk menampilkan garis koordinat (longitude dan latiiude).

6. Landmask, untuk memberikan warna daratan pada citra.

7. Output data function, untuk memberikan keluaran atas citra yang ditampilkan, dapat berupa gambar citra dengan format $P N G$ atau berupa data dengan format ASCII.

8. Read and Profile, untuk membaca area melalui box data area.

9. Rline, untuk membaca data berdasarkan pada garis yang diplot pada citra.

10. Scale, untuk memberikan skala warna pada citra.

Dalam rangka evaluasi daerah penangkapan ikan tongkol, dalam kaitannya dengan kandungan konsentrasi klorofil-a, maka penyebaran klorofil-a pada setiap kotak (posisi penangkapan) dikelompokan tingkatannya (rendah, sedang, dan tinggi) sesuai dengan acuan yang dikatakan oleh Gower diacu dalam Widodo, 1999 (Tabel 1).
Di samping kandungan klorofil-a, aspek komposisi hasil tangkapan (jumlah hasil tangkapan dan ukuran panjang ikan) juga digunakan untuk mengevaluasi kondisi daerah penangkapan ikan tongkol. Data hasil tangkapan ini dianalisis secara deskriptif menurut skala ruang (penyebaran daerah penangkapan) dan waktu operasi penangkapan.

Penilaian terhadap ukuran panjang ikan dilakukan dengan menggunakan kriteria seperti disajikan pada Tabel 2. Kriteria pada Tabel 2 didasarkan pada sebaran umum ikan tongkol untuk memijah (gonade maturity) di perairan tropis, yaitu $40 \mathrm{~cm}$ (Collete \& Naueun diacu dalam Ismajaya, 2007), lalu ditentukan nilai bobot.

Penilaian jumlah hasil tangkapan didasarkan pada pendekatan upah minimum regional di Kabupaten Sukabumi, yaitu Rp. $450.000,00$ per bulan, sebagai pembanding terhadap penerimaan nelayan atas hasil tangkapan yang diperoleh. Nilai upah minimum regional dikonversi dalam satuan harian, selanjutnya dibandingkan dengan nilai penjualan ikan tongkol yang tertangkap per trip ( 1 trip $=1$ hari atau one day trip). Harga rata-rata ikan tongkol tiap kg berkisar antara Rp.4.000,00-5.000,00. Hasil penjualan kemudian dibagi sesuai dengan jumlah anak buah kapal. Dengan perhitungan tersebut diperoleh kategori hasil tangkapan (sedikit, sedang, dan banyak) lalu nilai bobotnya ditetapkan sebagaimana disajikan pada Tabel 3.

Pengaruh masing-masing indikator ukuran panjang, jumlah tangkapan, dan kandungan klorofil-a terhadap penentuan daerah penangkapan diasumsikan sama, sehingga bobot masing-masing indikator diakumulasikan dalam evaluasi daerah penangkapan ikan.

\section{HASIL DAN BAHASAN}

\section{Hasil Penelitian}

\section{Hubungan klorofil-a dengan hasil tangkapan}

Penyebaran kandungan klorofil-a secara temporal (bulan Maret-Mei 2007) di perairan Pelabuhanratu dapat terlihat secara lengkap pada citra, seperti contoh citra klorofil-a (Gambar 1). Selanjutnya konsentrasi klorofil-a pada setiap posisi penangkapan dan pada waktu yang bersamaan dengan kegiatan penangkapan ikan tongkol di perairan Pelabuhanratu dalam periode bulan Maret-Mei 2007 disajikan pada Gambar 2. Dari Gambar 2 terlihat bahwa penyebaran konsentrasi klorofil-a secara temporal cenderung berfluktuasi pada periode bulan Maret-Mei 2007. 
Tabel 1. Nilai skoring (pembobotan) menurut konsentrasi klorofil-a Table 1. Scoring value according to chlorophyll-a concentration

\begin{tabular}{cccc}
\hline No. & $\begin{array}{c}\text { Konsentrasi klorofil-a/ } \\
\text { Chlorophill-a concentration }\left(\mathbf{m g ~ m}^{-3}\right)\end{array}$ & $\begin{array}{c}\text { Penilaian/ } \\
\text { Scoring }\end{array}$ & $\begin{array}{c}\text { Bobot/ } \\
\text { Point }\left({ }^{*}\right)\end{array}$ \\
\hline 1. & $0,0-0,1$ & sedikit & 2 \\
2. & $0,1-0,2$ & sedang & 4 \\
3. & $0,2-0,6$ & banyak & 6 \\
\hline
\end{tabular}

Keterangan/Remarks: $\left(^{\star}\right)$ ditentukan berdasarkan pada teknik skoring

Sumber/Sources: Gower (1972) diacu dalam Widodo (1999)

Tabel2. Nilai skoring (pembobotan) menurut ukuran panjang ikan tongkol

Table 2. Scoring value according to length size of frigate mackerel

\begin{tabular}{|c|c|c|c|}
\hline No. & $\begin{array}{l}\text { Ukuran panjang/ } \\
\text { Length size }(\mathrm{cm})\end{array}$ & $\begin{array}{l}\text { Penilaian/ } \\
\text { Scoring }\end{array}$ & $\begin{array}{l}\text { Bobot/ } \\
\left.\text { Scoring value/( }{ }^{\star}\right)\end{array}$ \\
\hline 1. & $x<30 ; x>40$ & tidak layak tangkap & 3 \\
\hline 2. & $30 \leqslant x \leqslant 40$ & layak tangkap & 6 \\
\hline \multicolumn{4}{|c|}{$\begin{array}{l}\text { Keterangan/Remarks: }\left({ }^{*}\right) \text { ditentukan berdasarkan pada teknik skoring } \\
\text { Sumber/Sources: Collete \& Naueun diacu dalam Ismajaya }(2006)\end{array}$} \\
\hline $\begin{array}{l}\text { Tabel } 3 . \\
\text { Table } 3 .\end{array}$ & \multicolumn{3}{|c|}{$\begin{array}{l}\text { Nilai skoring (pembobotan) menurut jumlah hasil tangkapan ikan tongkol } \\
\text { Scoring value according to catch number of frigate mackerel }\end{array}$} \\
\hline No. & Tangkapan/Catch (kg/trip) & Penilaian/Scoring & Bobot/Scoring value $\left({ }^{*}\right)$ \\
\hline 1. & $\mathrm{HT} \leqslant 300$ & sedikit & 2 \\
\hline 2. & $3.400 \leqslant H T<800$ & sedang & 4 \\
\hline 3. & $\mathrm{HT} \geqslant 800$ & banyak & 6 \\
\hline
\end{tabular}

Keterangan/Remarks: (*) ditentukan berdasarkan pada teknik skoring

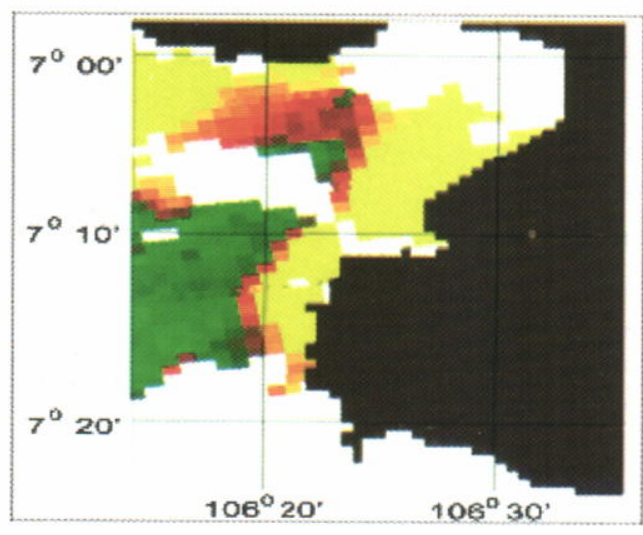

Citra tanggal 21 April 2007

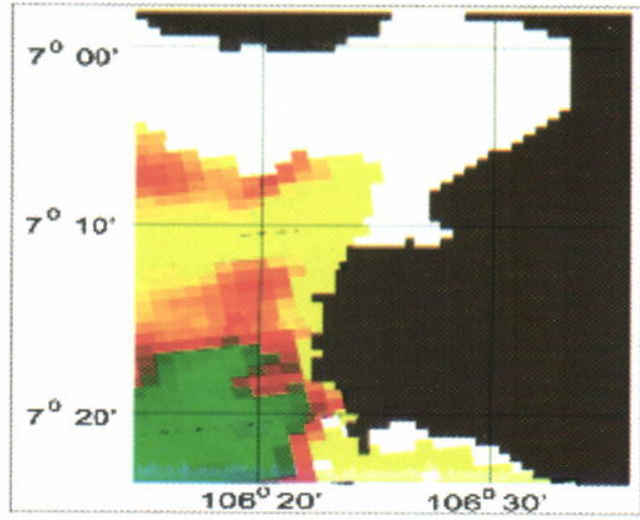

Citra tanggal 7 Mei 2007

Gambar 1. Contoh citra clorofil-a tanggal 21 April dan 7 Mei 2007.

Figure 1. Sample of chlorophyll-a image on April 21 and May 7, 2007.

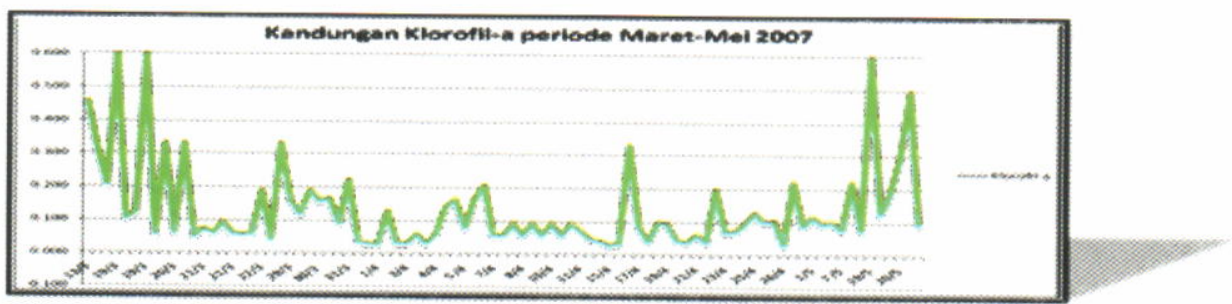

Gambar 2. Fluktuasi konsentrasi klorofil-a bulan Maret-Mei 2007.

Figure 2.

Fluctuation of chlorophyll-a concentration on March-May 2007. 
Jumlah tangkapan total pada bulan Maret-Mei 2007 mencapai $86,241 \mathrm{~kg}$. Hasil tangkapan terbanyak diperoleh pada bulan April, yaitu 62,638 kg (72,63\%), kemudian menyusul pada bulan Maret dan Mei 2007 masing-masing $15.345 \mathrm{~kg}(17,79 \%)$ dan $8.258 \mathrm{~kg}$ $(9,58 \%)$. Jumlah tangkapan paling rendah terdapat pada bulan Mei, namun produktivitasnya atau catch per unit of effort lebih tinggi dibandingkan bulan Maret (Gambar 3).

Korelasi silang antara klorofil-a dengan jumlah tangkapan tongkol disajikan pada Gambar 4. Dari Gambar 4 terlihat bahwa time lag atau jarak korelasi terjadi pada hari ke-30. Hasil uji ini diperkuat oleh analisis deskriptif yang disajikan pada Gambar 5, yang menunjukkan bahwa hasil tangkapan ikan tongkol baru meningkat secara nyata pada tanggal 14 April 2007 walaupun konsentrasi klorofil-a sudah tinggi mulai tanggal 13 Maret 2007(time lag 30 hari).

\section{Evaluasi daerah penangkapan ikan tongkol}

Daerah penangkapan ikan tongkol di Pelabuhanratu pada bulan April lebih baik dibandingkan dengan bulan Maret dan Mei 2007 karena jumlah tangkapan dan produktivitasnya lebih tinggi pada bulan April (Gambar 3). Di samping itu, komposisi ikan yang layak tangkap juga lebih banyak pada bulan April (Gambar 6). Daerah penangkapan ikan tongkol pada bulan Mei 2007 lebih baik dibandingkan dengan bulan Maret 2007 walaupun pada bulan Maret jumlah tangkapan lebih banyak. Hal ini disebabkan karena produktivitas bulan Mei lebih tinggi dibandingkan Maret (Gambar 3) dan komposisi ikan yang masuk kategori layak tangkap juga lebih banyak pada bulan Mei (Gambar 6). Pada Gambar 6 terlihat bahwa hasil tangkapan tongkol di perairan Pelabuhanratu dalam periode bulan Maret-Mei 2007 lebih didominansi oleh kategori tidak layak tangkap, yaitu $73 \%$. Sedangkan ikan tongkol yang layak tangkap hanya $27 \%$, dengan komposisi tertinggi pada bulan April (33\%), kemudian menyusul pada bulan Mei (23\%), dan terakhir pada bulan Maret (19\%).
Berdasarkan pada indikator produktivitas tangkapan, ukuran panjang ikan tongkol yang tertangkap, dan kandungan klorofil-a di perairan, maka daerah penangkapan ikan (DPI) tongkol di perairan Pelabuhanratu dikategorikan menjadi tiga, yaitu DPI potensial, sedang dan kurang potensial. Hasil penilaian DPI ikan tongkol di perairan Pelabuhanratu pada periode bulan Maret-Mei 2007 disajikan dalam bentuk peta tematik (Gambar 7). Dari gambar terlihat bahwa frekuensi timbulnya DPI potensial terbanyak pada bulan April 2007, kemudian menyusul pada bulan Mei dan April 2007.

\section{Bahasan}

Jumlah tangkapan ikan tongkol terbanyak terdapat pada bulan April 2007 dan paling rendah pada bulan Mei 2007. Rendahnya hasil tangkapan pada bulan Mei terkait erat dengan jumlah setting yang lebih sedikit, yaitu hanya 13 kali setting (Gambar 8). Walaupun jumlah tangkapan paling rendah bulan Mei, tetapi produktivitasnya atau catch per unit of effort lebih tinggi dibandingkan dengan bulan Maret. Produktivitas bulan Mei berkisar $95-1460 \mathrm{~kg} /$ setting dengan rata-rata $401,55 \mathrm{~kg} /$ setting, sedangkan pada bulan Maret, berkisar $35-800 \mathrm{~kg} /$ setting dengan ratarata $272,27 \mathrm{~kg} /$ setting. Selanjutnya pada bulan April, produktivitas relatif lebih tinggi dibandingkan bulan Maret dan Mei, yaitu berkisar 164,50-3.200 kg/setting dengan rata-rata $701,04 \mathrm{~kg} /$ setting.

Kondisi cuaca yang kurang kondusif turut berpengaruh terhadap pengoperasian payang dalam memanfaatkan daerah penangkapan ikan tongkol di perairan Pelabuhanratu. Hal ini sesuai dengan pendapat Simbolon (2008), bahwa pengaruh angin muson barat terasa kuat pada bulan Maret dan semakin melemah pada bulan April dan Mei. Akibatnya, pada bulan Maret dengan pengaruh angin barat lebih terasa, maka angin akan bertiup lebih kencang di perairan Pelabuhanratu. Dengan demikian, peluang nelayan semakin kecil untuk memanfaatkan

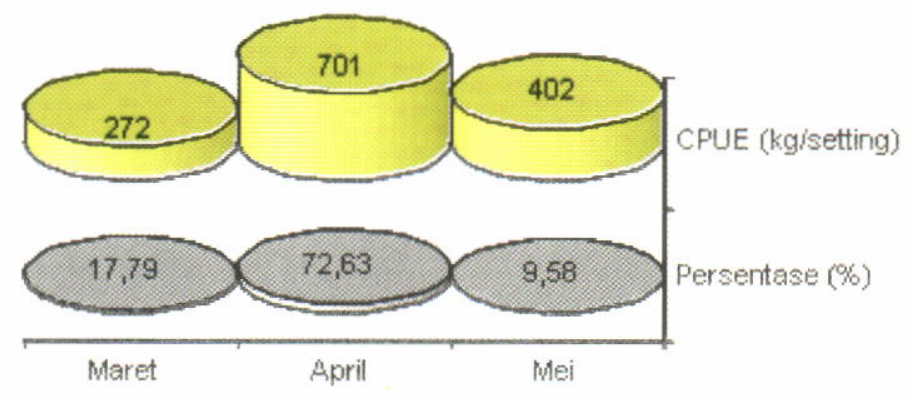

Gambar 3. Catch per unit effort dan persentase jumlah tangkapan ikan tongkol bulan Maret-Mei 2007. Figure 3. $\quad$ Catch per unit effort and percentage of frigate mackerel catch number on March-May 2007. 


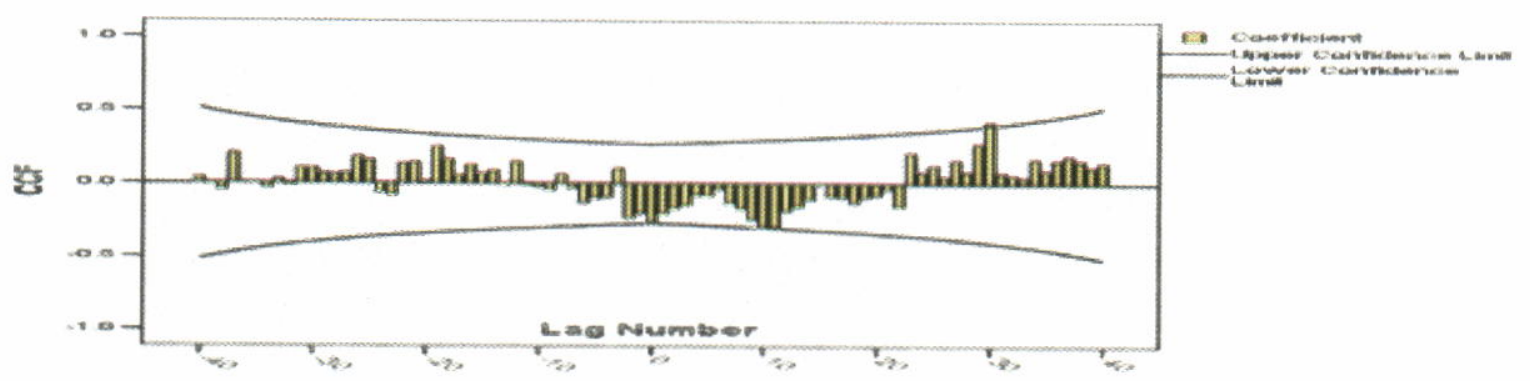

Gambar 4. Korelasi silang antara klorofil-a dan hasil tangkapan.

Figure 4. Cross correllation between chrolophyll-a and catch.

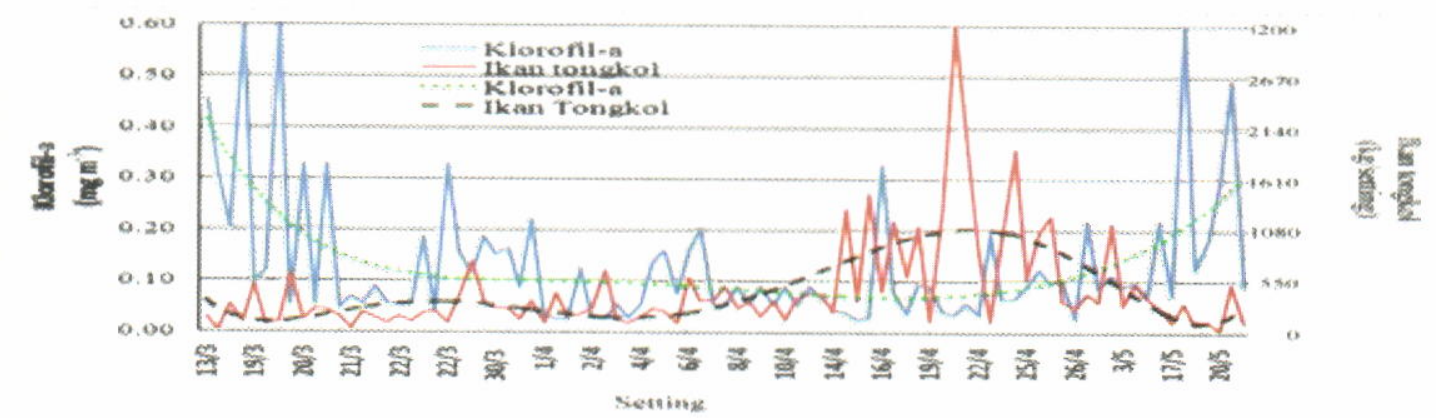

Gambar 5. Klorofil-a menunjukkan pengaruh nyata terhadap tangkapan ikan tongkol pada time lag 30 hari (tanggal 14 April 2007).

Figure 5. Chlorophyll-a showing significantly influences on frigate mackerel catch at 30 days of time lag (April 14 $4^{\text {th }}$ 2007).

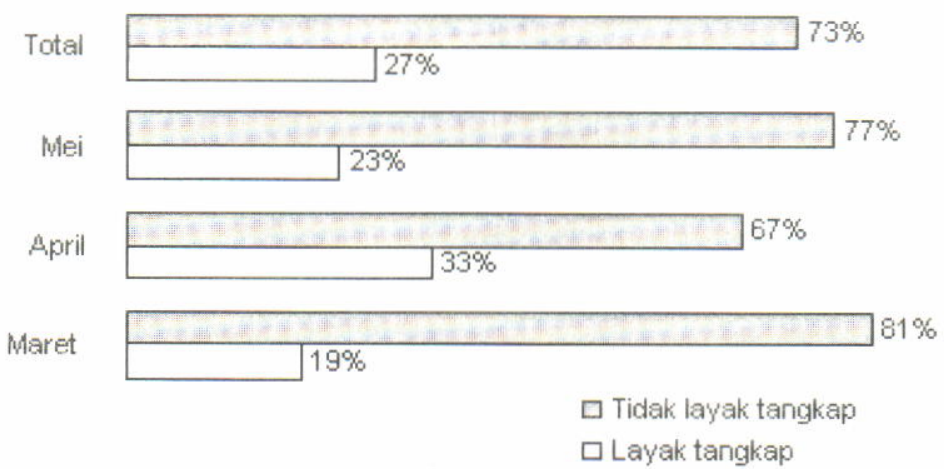

Gambar 6. Persentase jumlah tangkapan ikan tongkol yang layak tangkap dan tidak layak tangkap bulan Maret-Mei 2007.

Figure 6. Percentage of frigate mackerel catch number which biologically justified and not biologically justified on March-May 2007.

DPI yang kondusif dan produktivitas pun menjadi lebih rendah pada bulan Maret dibandingkan dengan bulan April dan Mei.

Di samping pengaruh intensitas penangkapan, hasil tangkapan ikan tongkol yang berfluktuasi di perairan Pelabuhanratu juga diduga karena pengaruh variabilitas parameter-parameter oseanografi, seperti suhu, salinitas, kesuburan perairan, dan lain-lain.
Kandungan klorofil-a yang dihasilkan oleh fitoplankton merupakan indikasi kesuburan perairan, dan fitoplankton sangat penting sebagai produser primer (primary producer) dalam proses rantai makanan. Dengan demikian, fitoplankton yang berfluktuasi akan turut berperan dalam menentukan keberadaan musim ikan tongkol di perairan. Dugaan ini diperkuat oleh pendapat Shtraikhert \& Zakharkov (2002) dan Gaol et al. (2004), yang mengatakan bahwa kandungan 
klorofil-a yang dihasilkan oleh fitoplankton cenderung berfluktuasi secara musiman, sehingga kesuburan perairan juga akan cenderung bervariasi secara musiman. Namun demikian, informasi tentang variabilitas kesuburan daerah penangkapan ikan tongkol secara temporal jarang dilakukan. Untuk itu perlu dilakukan observasi yang lebih mendalam tentang variabilitas fitoplankton (klorofil-a) di daerah penangkapan ikan tongkol secara temporal dengan menggunakan data time series yang memadai.

Kandungan klorofil-a yang tinggi pada bulan Maret tidak langsung diikuti oleh nilai catch per unit of effort yang tinggi. Konsentrasi klorofil-a sebagai indikasi keberadaan fitoplankton yang terdapat di perairan tidak secara langsung mempengaruhi jumlah ikan tongkol di perairan Pelabuhanratu. Konsentrasi klorofil-a yang tinggi pada bulan Maret baru berpengaruh nyata terhadap jumlah hasil tangkapan pada bulan April setelah 30 hari. Terdapatnya time lag 30 hari ini diduga terkait erat dengan adanya proses rantai makanan, yang mana fitoplankton dimakan oleh tingkat tropik di atasnya seperti zooplankton ataupun ikan kecil (Nybakken, 1992; Gabric \& Parslow, 1989). Selanjutnya setelah 30 hari dari awal meningkatnya kandungan klorofil-a, ikan tongkol semakin banyak untuk memanfaatkan tingkat tropik di bawahnya sebagai sumber makanan (Gambar 9).

Persentase hasil tangkapan ikan tongkol di perairan Pelabuhanratu pada bulan Maret-Mei 2007 didominansi oleh ikan yang tidak layak tangkap, karena ukuran panjang yang tertangkap pada bulan Maret berkisar 24,67-40,00 cm dengan rata-rata 29,57 $\mathrm{cm}$, pada bulan April berkisar 25,00-45,00 cm dengan rata-rata $31,40 \mathrm{~cm}$, dan pada bulan Mei berkisar 20,00-
$40,00 \mathrm{~cm}$ dengan rata-rata $30,73 \mathrm{~cm}$. Hal ini mengindikasikan walaupun hasil tangkapan secara finansial menguntungkan, namun berdasarkan pada tinjauan aspek lingkungan dan biologis ternyata kurang baik. Hal ini sesuai dengan pernyataan Simbolon (2004) bahwa potensial atau tidaknya suatu daerah penangkapan tidak hanya dinilai dari kuantitas tangkapan, akan tetapi juga memperhatikan kualitas tangkapan (nilai ekonomis ikan dan komposisi ukuran ikan). Untuk mengurangi eksploitasi ikan yang belum layak tangkap secara biologi, maka dibutuhkan kebijakan yang tepat, terkait dengan pengaturan atau pemanfaatan daerah penangkapan. Dalam hal ini, dibutuhkan data dan informasi yang lebih lengkap dengan data time series yang lebih lama, tentang sebaran ukuran ikan berdasarkan pada skala spasial (daerah penangkapan) dan temporal (musim). Namun dalam penelitian ini, data temporal yang diperoleh sangat minim (bulan Maret-Mei 2007).

Setelah diperoleh data yang lebih representatif langkah selanjutnya adalah meningkatkan peran serta pemerintah daerah dan stakeholder lainnya untuk kegiatan sosialisasi, bahkan membuat suatu regulasi yang mengatur ukuran ikan yang boleh ditangkap dan sekaligus memberikan arahan kepada usaha penangkapan. Berdasarkan pada hasil penelitian ini (Gambar 6) usaha penangkapan ikan tongkol sebaiknya lebih mengintensifkan operasi penangkapan pada bulan April dibandingkan bulan Maret dan Mei. Jika diasumsikan penyebaran ikan yang masuk dalam kategori layak tangkap lebih banyak pada bulan April, maka peluang nelayan memperoleh ikan yang layak tangkap akan lebih besar.
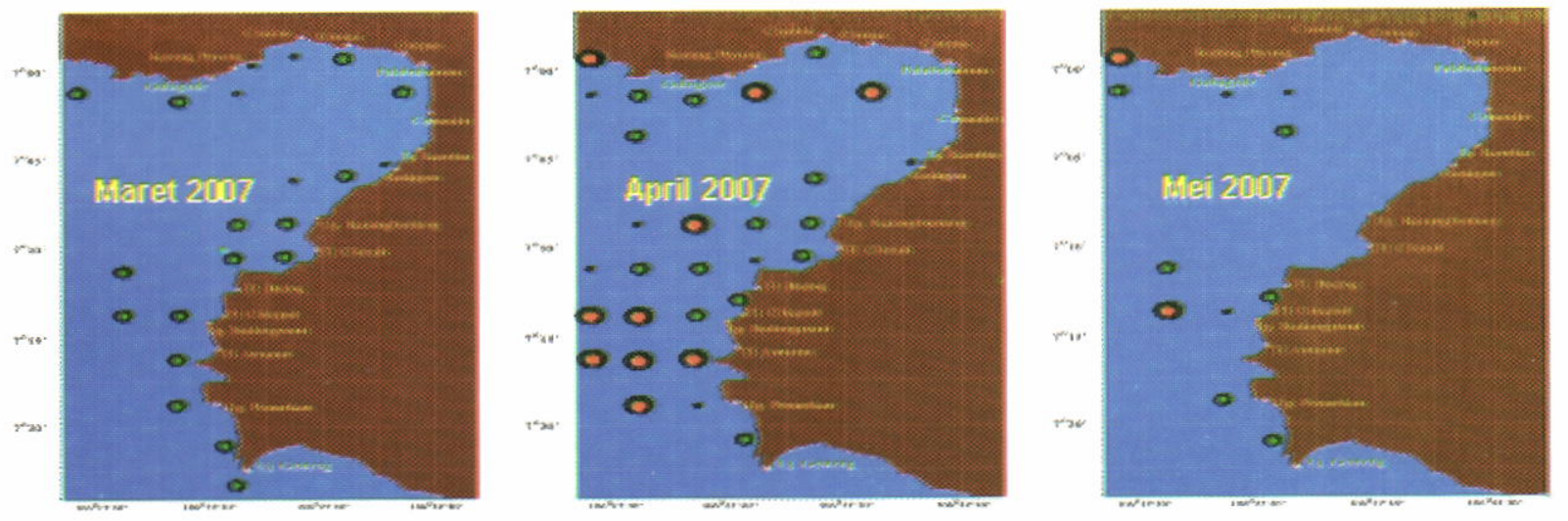

Gambar 7. Penyebaran daerah penangkapan ikan tongkol di perairan Pelabuhanratu, bulan Maret-Mei 2007.

Figure 7. Fishing ground distribution of frigate mackerel in Pelabuhanratu waters, March-May 2007. 

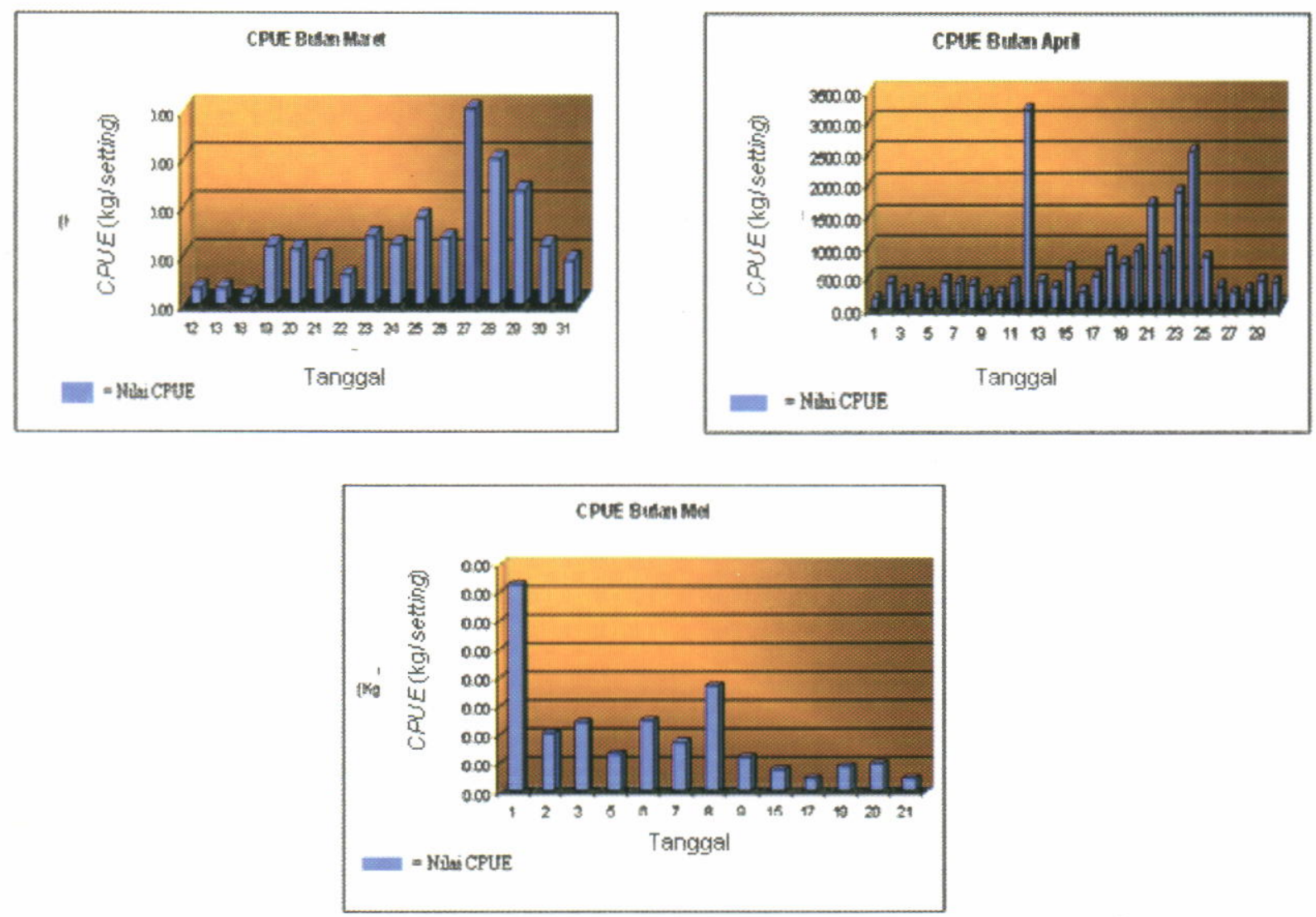

Gambar 8 .

Figure 8.

Catch per unit of effort pada bulan Maret-Mei 2007.

Catch per unit of effort on March-May 2007.

Fitoplankton

Zooplankton

Ikan kecil

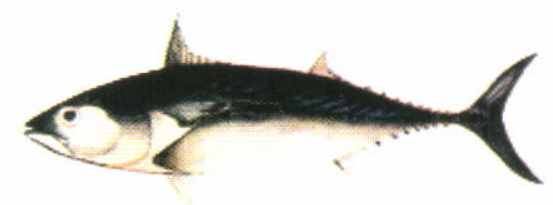

Ikan tongkol

Gambar 9. Rantai makanan yang dimulai dari fitoplankton sampai ikan tongkol. Figure 9. Food chain, which started from phytoplankton until frigate mackerel.

\section{KESIMPULAN DAN SARAN}

\section{Kesimpulan}

Kandungan klorofil-a berpengaruh nyata terhadap jumlah tangkapan ikan tongkol di perairan Pelabuhanratu pada hari ke-30 dari awal meningkatnya konsentrasi klorofil-a. Daerah penangkapan ikan tongkol di perairan Pelabuhanratu yang lebih potensial terjadi pada bulan April dibandingkan dengan bulan Maret dan Mei 2007.

\section{Saran}

Saran yang dapat diberikan untuk menindaklanjuti penelitian ini, adalah:

1. Untuk mengetahui variabilitas hasil tangkapan dan perolehan informasi penyebaran ikan kategori layak tangkap atau tidak layak tangkap yang lebih akurat, maka dibutuhkan penelitian lanjutan dengan data time series yang lebih lengkap dalam periode minimal 5 tahun. 
2. Diperlukan penelitian lanjutan tentang karakteristik oseanografi lainnya yang berpengaruh terhadap pembentukan DPI ikan tongkol di perairan Pelabuhanratu secara bersamaan, seperti arus, suhu, upwelling, dan front.

3. Diperlukan upaya sosialisasi yang lebih intensif terutama kepada usaha penangkapan dan industri alat tangkap, terkait dengan komposisi ukuran panjang ikan tongkol yang layak tangkap-tidak layak tangkap.

\section{PERSANTUNAN}

Kegiatan penelitian menggunakan biaya sendiri, dilaksanakan bersamaan dengan penelitian skripsi mahasiswa di Departemen Pemanfaatan Sumber Daya Perikanan, T. A. 2007. Penulis mengucapkan terima kasih kepada Mario (mahasiswa Departemen Pemanfaatan Sumber Daya Perikanan, Institut Pertanian Bogor), Thomas (teknisi stasiun lapangan Institut Pertanian Bogor di Pelabuhanratu), dan nakhoda kapal payang yang telah membantu mengumpulkan data penelitian ini.

\section{DAFTAR PUSTAKA}

Gabric, A. J. \& J. Parslow. 1989. Effect of Physical Factor on the Vertical Distribution of Phytoplankton Eutrophyc Coastal Water. Australia Journal Marine Freshwater Resources. 189. 40: 559-569.

Gaol, J. L., Wudianto, B. Pasaribu, D. Manurung, \& R. Endriani. 2004. The Fluctuation of chlrophyll-a concentration de:ived from satellite imagery and catch of oily sardine (Sardinella lemuru) in Bali Strait. International Journal of Remote Sensing and Earth Sciences. IReSES. 1 : 24-30.

http:/oceancolor.gsfc.nasa.gov/cgi/seadas.

Ismajaya. 2007. Hubungan suhu permukaan laut dengan daerah penangkapan ikan tongkol pada musim timur di perairan Teluk Pelabuhan Ratu, Jawa Barat. Skripsi. (tidak dipublikasikan). Departemen Pemanfaatan Sumber Daya Perikanan. Fakultas Perikanan dan Ilmu Kelautan. Institut Pertanian Bogor. Bogor.

Nybakken, J. W. 1992. Biologi Laut Suatu Pendekatan Ekologis. Jakarta. PT. Gramedian.

Shtraikhert, E. A. \& S. P. Zakharkov. 2002. Investigation of the seasonal variability in the chlorophill-a concentration. Using SeaWIFS Data. PORSEC 2002. Bali. Indonesia. (tidak dipublikasikan).

Simbolon, D. 2008. Pendugaan daerah penangkapan ikan tongkol berdasarkan pendekatan suhu permukaan laut deteksi satelit dan hasil tangkapan di perairan Teluk Pelabuhan Ratu. Jurnalitbangda NTT. Kupang. Bulan Oktober-Desember. 04: 2330.

Simbolon, D. 2004. Suatu studi tentang potensi pengembangan sumber daya ikan cakalang dan teknologi penangkapan yang ramah lingkungan. Buletin PSP. Fakultas Perikanan dan IImu Kelautan. Institut Pertanian Bogor. Bogor. XIII. 1: 48-67.

Surwagana, N., A. Muchlisin, \& S. Hamzah. 2000. Penentuan Suhu Permukaan Laut dan Konsentrasi Klorofil-a untuk Pengembangan Model Prediksi SST atau Fishing Ground dengan Menggunakan Data Modis. Jakarta. LAPAN.

Widodo, J. 1999. Aplikasi teknologi penginderaan jauh untuk perikanan di Indonesia. Prosiding Seminar Validasi Data Inderaja untuk Bidang Perikanan. Jakarta 14 April 1999. Badan Pengkajian dan Penerapan Teknologi. Jakarta. ISBN: 979-957601-6. (II-1-II-21). 
